\title{
Serum heavy metals in patients with fragments and shells of improvised explosive devices
}

\author{
Mahmood A. Aljumaily*, Nabeel H. Alfhady**, Mr. Mowafak K. Hassan*** \\ * Department of Surgery, ** Department of Anatomy, Section of Biology, College of Medicine; \\ *** Department of Biology, College of Sciences, University of Mosul.
}

(Ann. Coll. Med. Mosul 2011; 37 (1 \& 2): 8-13).

Received: $10^{\text {th }}$ Oct 2010; Accepted: $25^{\text {th }}$ Apr 2011.

\begin{abstract}
Background: Iraq is the most affected country by injuries of improvised explosive devices (IED) including bomb car, bomb born on person and roadside bombs. Embedded fragments and shells can release heavy metal. High level of heavy metal in serum carries dangerous long term risk for injured patients.

Objective: The aim of this study is to estimate the serum level of heavy metals (copper, lead, cadmium, nickel, and zinc) in patients with fragments and shells from IED including bomb car, bomb born on person and roadside bombs.

Material and methods: Serum concentrations of heavy metals (copper, lead, cadmium, nickel, and zinc) were assayed using atomic absorption spectrophotometry in 52 patients with fragments and shells from IED. Serum concentrations of heavy metals were measured in 52 healthy adults as control group.

Results: The mean serum level of copper, lead, cadmium, nickel, and zinc in patients were $1304 \pm$ $258.1 \mu \mathrm{g} / \mathrm{L}, 36.5 \pm 16.7 \mu \mathrm{g} / \mathrm{L}, 6.203 \pm 2.372 \mu \mathrm{g} / \mathrm{L}, 0.387 \pm 0.183 \mu \mathrm{g} / \mathrm{L}$, and $1651 \pm 532 \mu \mathrm{g} / \mathrm{L}$ respectively, while in control were $824.2 \pm 203.6 \mu \mathrm{g} / \mathrm{L}, 31 \pm 15.1 \mu \mathrm{g} / \mathrm{L}, 1.654 \pm 0.4 \mu \mathrm{g} / \mathrm{L}, 0.239 \pm$ $0.028 \mu \mathrm{g} / \mathrm{L}, 619 \pm 234 \mu \mathrm{g} / \mathrm{L}$ respectively. The differences in serum copper, lead, cadmium, nickel, and zinc between patient and control is highly significant, ( $P$ value $<0.0001)$, while the differences in serum lead between patient and control is not significant ( $P$ value $>0.05$ ).

Conclusion: The present study demonstrates that a highly significant increase in serum level of copper, cadmium, nickel, and zinc in patient with fragments and shells from IED in comparison with control group, while the difference in serum lead in patients and control was not significant.
\end{abstract}

Keywords: Improvised explosive devices, fragment, shell, metal, serum level.

الخلفية: العر اق هو البلد الأكثر نتأثرا بإنفجارات السيار ات المفخخة والعبوات والأحزمة الناسفة وان الثظايا الداخلة في

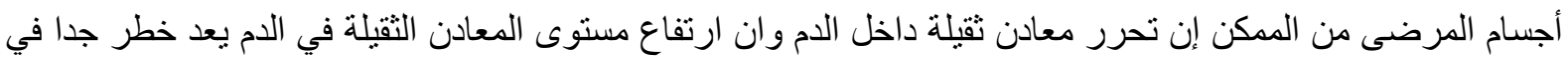
المرضى المصابين. الأهداف: إن هدف الدراسة هو تحديد مستوى المعادن الثقيلة (النحاس، الرصاص، الكادميوم، النيكل و الزنك) في دم

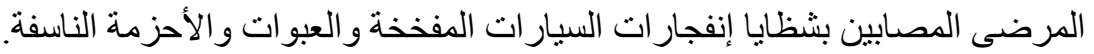
المواد وطريقة العمل: تم قياس مستوى المعادن الثقيلة (النحاس، الرصاص، الكادميوم، النيكل والزنانك) بواسطة جهاز امتصاص الطيف الضوئي الذري في دم

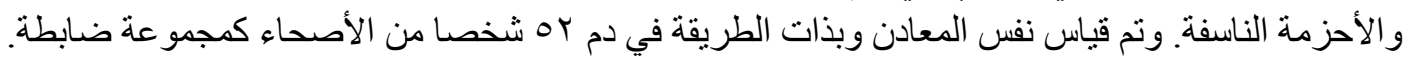




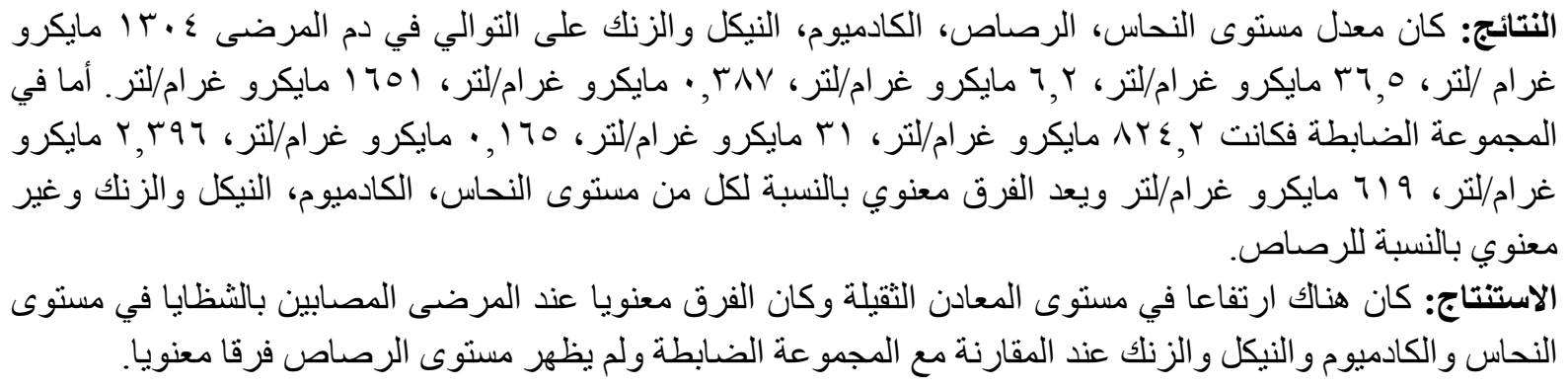

$\mathrm{T}$ he improvised explosive devices (IED) ranged from bombs born on persons and bomb cars to roadside bombs (1). The explosive weapons in populated areas consistently cause unacceptable level of harm to civilians, this pattern of harm is seen in individual incidents of violence as well as in major conflicts ${ }^{(1)}$. Explosive weapons produce a common pattern of wounding with variations depending on the force of blast, size of fragments, location of the blast, and susceptibility of the individual victims ${ }^{(1)}$. The mechanisms of injury from blast have been divided into primary (effect of blast wave on organs and tissues), secondary (injuries caused by propagated flying debris and bomb fragments projection into body), tertiary ( effect of blast wind cause propulsion of body into other objects) and quaternary (all other injuries and diseases following blast trauma) $)^{(1,2)}$. Primary Fragmentation can be part of the bomb casing itself or objects intentionally imbedded into the IED designed to cause further wounding like nails, screws, nuts, bolts and many variable materials, and any local material that was made airborne by projectile (secondary fragmentation) ${ }^{(1,2)}$.

IED cause complex patterns of wounding and numerous penetrating wounds containing embedded fragments that require greater medical resources than other trauma. For survivors, immediate injuries can result in a range of long term physical condition (1). Information accumulated in the last 6 years in Iraq shows an increase in oncological, chronic and reproductive diseases and malformations at birth, particularly high in the areas most severely attacked (3). It is well-known that excess of the heavy metals can disrupt body functions and have pathogenic effects on human respiratory organs, kidney, skin and affect sexual and neurological development and functions ${ }^{(3-6)}$. Cadmium, and nickel are known to be human toxic, carcinogenic and teratogenic. Lead, copper and zinc are wellknown human multi-systemic toxic and fetotoxic $^{(3-6)}$. Systemic lead toxicity following gunshot, has been reported to occur anywhere from 2 days to 40 years after intra-articular gunshot injury ${ }^{(7)}$.

In our community there is an un-estimated large number of injured patients with fragments and shells after explosion. There are no available studies on the level of heavy metals after injuries with fragments and shells of IED. The aim of this study is to estimate the serum level of copper, lead, cadmium, nickel and zinc in patients with fragments and shells from IED including bomb car.

\section{Material and methods}

This study was approved by the scientific research committee at the College of Medicine, University of Mosul. A written informed consent was obtained from all patients and controls. The chemical analysis and metal serum level measurement were conducted at laboratories of College of Medicine and College of Sciences, University of Mosul, during the period from September 2009 to September 2010. Fifty two patients with symptoms related to fragments and shell of IED including bomb cars, person born bombs, and road side bombs included in this study. All patients collected from the department of orthopedic surgery, Aljumhori Teaching Hospital, they had either pain at site of foreign body, acute flare up of infection or 
chronic discharging sinus. Forty four patients were males and 8 were females. The mean age of patients was 33.9 years \pm 10 , ranged 4 to 68 years. Forty six patients were injured in bomb cars while 4 patients injured by road side bombs and 2 by person born bomb. Forty nine patient had multiple shells and only 3 patients had a single shell. The mean duration between injury and samples taking was 14.6 months, ranged between one month to 6 years. Fifty two healthy adults share as a control group, they donated $10 \mathrm{ml}$ of blood for chemical analysis for heavy metals. The control group mean age was 33.1 years \pm 13 ranged 18 to 62 years, 28 of them were males and 24 were females.

All patients and controls were clinically examined. The exclusion criteria for patients and control were: the presence or history of any orthopedic or dental implants, renal insufficiency or chronic renal disease, or chronic medical treatment for systemic or local diseases, to avoid any bias in the serum metal determination.

\section{Preparation of samples}

Ten milliiters of venous blood was drawn from each patient and control. Blood samples were taken by blood sampling kit dedicated to trace element determination to avoid metal contamination. Serum samples were lysed for analysis of heavy metals by adding $10 \mathrm{ml}$ $\mathrm{HNO} 3$ to one $\mathrm{ml}$ of serum and heated at $60-$ $70 \mathrm{C}^{\circ}$ for 3-4 hours. Then $1 \mathrm{ml}$ perchloric acid was added to the same sample. Digestion process continued until the solution was clear.
Atomic absorption spectrophotometry flameless method was used to determine serum lead, cadmium and nickel by using Shimadzu AA-6650G instrument with electronic double beam Graphite Furnace Atomic Absorption (GFAA) spectrophotometer. The copper and zinc serum level were measured with the flame atomic absorption spectrophotometer.

\section{Statistical analysis}

Results were reported as mean \pm standard deviation. The unpaired two tail student ( $t$ ) test used to calculate the differences between two means. The $P$ value was considered significant if it was less than 0.05 .

\section{Results}

The mean age of patients was 33.9 years \pm 10 , the mean age of control group were 33.1 years \pm 13 . Serum copper mean in patients with fragments and shells of IED was $1304 \pm$ $258.1 \mu \mathrm{g} / \mathrm{L}$, while in control group was $824.2 \pm$ 203.6. The difference between the two means was highly significant $(P$ value $<0.0001)$, (table 1). The mean of blood lead in patients with shells and fragments of IED was $36.5 \pm$ $16.7 \mu \mathrm{g} / \mathrm{L}$, while in control group was $31 \pm$ 15.1. The difference between the two means was not significant ( $P$ value was 0.067 ), (table 1). The mean of blood cadmium in patients with shells and fragments of IED was $6.203 \pm$ $2.372 \mu \mathrm{g} / \mathrm{L}$, while in control group was $1.654 \pm$ 0.4 . The difference between the two means was highly significant $(P$ value $<0.0001)$, (table 1).

Table (1) : Serum metals in patients with fragments and shells of IED and control.

\begin{tabular}{|c|c|c|c|c|c|}
\hline \multirow{2}{*}{\multicolumn{2}{|c|}{ Serum metals }} & \multicolumn{2}{|c|}{ Serum level } & \multirow[b]{2}{*}{$p$ - value } & \multirow[b]{2}{*}{ Significance } \\
\hline & & \multirow{2}{*}{$\begin{array}{c}\text { mean } \\
1304.6 \mu \mathrm{g} / \mathrm{L}\end{array}$} & \multirow{2}{*}{$\begin{array}{c}\begin{array}{c}\text { Standard } \\
\text { deviation }\end{array} \\
258.1 \\
\end{array}$} & & \\
\hline \multirow{2}{*}{ copper } & Patients & & & \multirow{2}{*}{.0001} & \multirow{2}{*}{$\begin{array}{l}\text { Highly } \\
\text { significant }\end{array}$} \\
\hline & Control & $824.2 \mu \mathrm{g} / \mathrm{L}$ & 203.6 & & \\
\hline \multirow{2}{*}{ lead } & Patients & $36.5 \mu \mathrm{g} / \mathrm{L}$ & 16.7 & \multirow{2}{*}{.067} & Not \\
\hline & Control & $31 \mu \mathrm{g} / \mathrm{L}$ & 15.1 & & significant \\
\hline \multirow{2}{*}{ cadmium } & Patients & $6.20 \mu \mathrm{g} / \mathrm{L}$ & 2.37 & \multirow{2}{*}{.0001} & Highly \\
\hline & Control & $1.65 \mu \mathrm{g} / \mathrm{L}$ & 0.40 & & significant \\
\hline \multirow{2}{*}{ nickel } & Patients & $0.387 \mu \mathrm{g} / \mathrm{L}$ & 0.183 & \multirow{2}{*}{.0001} & Highly \\
\hline & Control & $0.239 \mu \mathrm{g} / \mathrm{L}$ & 0.028 & & significant \\
\hline \multirow{2}{*}{ zinc } & Patients & $1651 \mu \mathrm{g} / \mathrm{L}$ & 532 & \multirow{2}{*}{.0001} & \multirow{2}{*}{$\begin{array}{c}\text { Highly } \\
\text { significant }\end{array}$} \\
\hline & Control & $619 \mu \mathrm{g} / \mathrm{L}$ & 234 & & \\
\hline
\end{tabular}


The mean of serum nickel in patients with shells and fragments of IED was $0.387 \pm 0.183$ $\mu \mathrm{g} / \mathrm{L}$, while in control group was $0.239 \pm 0.028$. The difference between the two means was highly significant $(P$ value $<0.0001)$, (table 1$)$. The mean of serum zinc in patients with shells and fragments of IED was $1651 \pm 532 \mu \mathrm{g} / \mathrm{L}$, while in control group was $619 \pm 234$. The difference between the two means was highly significant ( $P$ value $<0.0001)$, (table 1$)$.

\section{Discussion}

In Iraq gunfire remains the most common cause of death, and deaths from car bombing have increased ${ }^{(8)}$. The expected numbers of injured patients would be much higher ${ }^{(9)}$. Iraq is the country most affected by injuries of IED weapons ${ }^{(1)}$. Bomb blast injuries are no longer confine to battlefield ${ }^{(10)}$.

Data from Iraq suggest that explosive weapons, by comparison with other weapons types, have higher proportion of child and female deaths and injuries (1). Explosive weapons injuries represent a demanding surgical emergency ${ }^{(11)}$. Heavy metal high level in serum carries dangerous long term risk for injured patients of IED ${ }^{(1)}$. It is recommended to evaluate serum heavy metals in all patients with retained bullet and fragments ${ }^{(12)}$.

In our study, there was highly significant difference in the level of serum copper between patients and control, (table 1). This might be explained by the intended use of copper containing covers of bullet and missiles to increase the fragmentation in explosion. Copper is an essential nutrient that is incorporated into a number of metalloenzymes, exposure to excessive levels of copper can result in a number of adverse health effects including liver and kidney damage, anemia, immunotoxicity, developmental toxicity, and carcinogenic ${ }^{(13-15)}$. Copper serum level varied between $782-1690 \mu \mathrm{g} / \mathrm{L}^{(4,13-16)}$, the reference value of serum copper in normal healthy human is $830-1530 \mu \mathrm{g} / \mathrm{L}^{(17)}$.

There was no significant difference in the level of serum lead between patients with fragment and shells of IED and control, (table 1). Lead poisoning from retained bullet or missile is rare ${ }^{(12)}$. Lead is a dangerous highly toxic substance, exposure to which can produce a wide range of adverse health effects, it is harmful even in small amount. Humans get exposed to lead through their environment and diet ${ }^{(4,18,19)}$. Lead is a multitargeted toxicant, usually affect kidney and nervous system ${ }^{(4,18)}$. Lead toxicity remains one of the most important problems in terms of prevalence of exposure and public health impact ${ }^{(20)}$. Mean lead concentrations in blood, tibia, and patella were $3.5 \mu \mathrm{g} / \mathrm{dl}, 18.9 \mu \mathrm{g} / \mathrm{g}$ and $6.8 \mu \mathrm{g} / \mathrm{g}$ respectively ${ }^{(21)}$. There is variation in gender and race, normal level was $<5 \mu \mathrm{g} / \mathrm{dl}$ $(20,21)$

The level of serum cadmium shows a highly significant difference between patients and control, (table 1). This might be explained by the cadmium containing alloys used in cars and batteries used in explosion. Cadmium, a heavy metal is well known to be highly toxic to both human and animals. Cadmium exposure leads to long-term effects on human health even at low concentrations and it affect many systems, because cadmium confounds many physiological processes ${ }^{(22)}$. Cadmium serum level is variable in literatures ${ }^{(4,18,22)}$. Cadmium is toxic, carcinogenic and fetotoxic ${ }^{(4,18)}$.

There was highly significant difference in serum nickel between patients and control, (table 1). This might be explained by the wide use of nickel in cars bodies and parts, which produce many fragments and shells that contain nickel. Nickel is one of the heavy metals widely used in modern industry has been recognized as highly toxic to skin, respiratory system and reproductive system, and carcinogens ${ }^{(23,24,25)}$. Reference value for nickel in healthy adults is $0.2 \mu \mathrm{g} / \mathrm{L}$ in serum and $1-3 \mu \mathrm{g} / \mathrm{L}$ in urine, it reaches $2-6.5 \mu \mathrm{g} / \mathrm{L}$ in serum of nickel industry workers ${ }^{24,25)}$. The essentiality of nickel in humans has not been established, the nickel dietary recommendations has not been established for human $(24,25)$. Stainless steel endoprostheses may release nickel, also administration of nickel contaminated medications lead to significant exposure ${ }^{(25)}$.

Serum zinc in our study shows a highly significant difference between patients and control, (table 1). This might be explained by the wide use of zinc containing metallic parts 
in cars and in bomb designs. Zinc is an essential nutrient that is incorporated into a number of metalloenzymes, chronic zinc toxicity can impair cellular immunity and can cause hypochromic anemia ${ }^{(5,18)}$. The normal value of serum zinc varied in different studies, its ranged between $700-1348 \mu \mathrm{g} / \mathrm{L}^{(4,5,13-16,26)}$.

It is wise to follow up patients with shells and fragments of IED for metals toxicity. More studies should be done in this field since this is very common medical problem in our country which subjected to the most heroic explosions and violence. In conclusion, the present study demonstrates that embedded fragments and shells form IED including bomb car causes a highly significant elevation in metals (copper, cadmium, nickel, and zinc) concentration in serum, while serum lead shows no significant differences in patient in comparison with control.

\section{References}

1. Holmes J. Explosive Violence: The problem of explosive weapons. 2009. Humanitarian Affairs and Emergency Relief. New York: 10- 41.

2. Born CT. Blast trauma: The forth weapon of mass destruction. Scandinavian Journal of surgery. 2005; 94: 279-85.

3. Skaik $\mathrm{S}$, Abu-shaban N, Abu-shaban N, et al. Metal detected by ICP/MS in wound tissue of war injuries without fragments in Gaza. BMC International Health and human rights. 2010; 10: 17-31.

4. Popko J, Olszewski S, Hukałowicz K, Markiewicz $\mathrm{R}$, Borawska $\mathrm{M} \mathrm{H}$, Szeparowicz P. Lead, Cadmium, Copper and Zinc Concentrations in Blood and Hair of Mothers of Children with Locomotors System Malformations. Polish Journal of Environmental Studies 2003 ; 12: 375-379.

5. Russell RM, Suter PM. Vitamins and trace minerals deficiency and excess. In: Fuuci AS, Braunwald E, Kasper DL. Harrison's principle of internal medicine 2008. $17^{\text {th }}$ ed. McGraw Hill. New York : 441- 450.

6. McGuigan MA. Chronic poisoning: trace metals and other. In: Goldman L, Ausiello D. Cecil Medicine 2008. 23 ed. Saunders. Philadelphia: 102-110.
7. Wood GW. General principles of fractures treatment. In: Canale S, Beaty J. Campbell's operative orthopedics. 2008, $11^{\text {th }}$ ed. Mosby. Philadelphia: 3017-84.

8. Burnham G, Lafta R, Doocy S, Roberts L. Mortality after the 2003 invasion of Iraq: a cross-sectional cluster sample survey. Lancet. 2006; 368: 1421-8.

9. Biluka OO, Brennan M, Woodruff BA. Death and injury from landmines and unexploded ordnance in Afghanistan. JAMA. 2003; 290: 650-3.

10. Goh SH. Bomb blast mass casualty incidents: initial triage and management of injuries. Singapore Med J. 2009; 50: 1016.

11. Gressler GA, Leopold A, Germann G, Heitmann C. Blast injuries of the hand. Patterns of trauma and plastic surgical treatment. Unfallchirurg. 2006; 106: 95663.

12. Mahan ST, Murry MM, Woolf $A D$, Kasser $R$. Increased blood lead level in adolescent girl from retained bullet. J Bone Joint Surg. 2006; 88-A: 2726-9.

13. Zeyrek D, Soran M, Cakmak A, Kocyigit A, Iscan A. Serum Copper and Zinc Levels in Mothers and Cord Blood of their Newborn Infants with Neural Tube Defects: A Casecontrol Study. Indian Pediatrics . 2009; 46: 675- 80.

14. Faber S, Zinn GM, Kern JC, Kingston. The plasma zinc/serum copper ratio as a biomarker in children with autism spectrum disorders. Biomarkers.2009; 14: 171-80.

15. Dar NA, Mir MM, Salam I, ET AL. Association between copper excess, zinc deficiency, and TP53 mutations in esophageal squamous cell carcinoma from Kashmir Valley, India--a high risk area. Nutr Cancer. 2008; 60: 585-91.

16. Day AC, Shahidullah M, Mannan MA, Noor MK, Saha L, Rahman SA. Maternal and neonatal serum zinc level and its relationship with neural tube defects. J Health Popul Nutr. 2010; 28: 343-50.

17. Walker SW. Appendix. In: Boon NA, Colledge NR, Walker BR, Hunter JAA. Davidson's principle and practice of 
medicine 2006. 20 $0^{\text {th }}$ ed. Churchill Livingstone. Edinburgh. : 1320.

18. Al-Malki AL. Serum heavy metals and haemoglobin related compounds in Saudi Arabia firefighters. Journal of occupational medicine and toxicology 2009; 4: 18-29.

19. Salawa EO, Adeeyo OA, Falokun OP, Yusuf UA, Oyerinde A, Adeleke AA. Tomato prevents lead- induced testicular toxicity. J Hum Peprod Sci. 2009; 2: 30-34.

20. Hu H, Shih R, Rothenberg S, Schwartz BS. Epidimiology of lead toxicity in adult. Enviro Health Perspect. 2007; 115: 45562.

21. Theppeang K, Glass TA, Roche KB et al. Gender and race/ ethnicity differences in lead dose biomarkers. Am J Public Health. 2008; 98: 1248- 55.

22. Miura N. Individual susceptibility to cadmium toxicity and metallothionein gene polymorphisms. Industrial Health. 2009 ; 47 :487- 494.
23. Wang $S$, He $X$, An R. Responses of growth and antioxidant metabolism to nickel toxicity. Journal of animal and plant sciences. $2010 ; 7$ : 810- 821.

24. Ilic V, Bojanic V, Jovic B. Epidemiological and pathogentic aspects of nickel poisoning. Acta Medaca Medianae. 2007; 46: 37- 44.

25. Duda - Chodak A, Blaszczyk U. The impact of nickel on human health. J Elementol. 2008; 13 : 685- 96.

26. Kilinc M, Coskun A, Bilge F, Imrek SS, Atli $Y$. Serum references level of selenium, zinc and copper on healthy pregnant women at a prenatal screening program in southeastern Mediterranean region of turkey. J Trace Elem Med Biol. 2010; 24: 152-6. 